\title{
Discovery of missing proteins from an aneuploidy cell line using proteogenomic approach
}

Fanyu Bu ${ }^{1,4}$, Qingqiu Cheng ${ }^{2}$, Yuxing Zhang ${ }^{1,4}$, Xia Zhang ${ }^{1,4}$, Keqiang Yan ${ }^{1,4}$, Frank $\mathrm{Liu}^{1}$, Zelong $\mathrm{Li}^{3}$, Xiaomei $\mathrm{Lu}^{2}$, Yan $\mathrm{Ren}^{1 *}$ and Siqi Liu ${ }^{1,4^{*}}$

${ }^{1}$ BGI-Shenzhen, Beishan Industrial Zone 11th building, Yantian District, Shenzhen, Guangdong, China, 518083

${ }^{2}$ Clinical laboratory center of Dongguan Eighth People's Hospital Dongguan, China, 523325

${ }^{3}$ Biological Resource Center of Plants, Animals and Microorganisms, China National Gene Bank, BGI-Shenzhen, Guangdong, China, 518120

${ }^{4}$ Department of BGI education, School of Life Sciences, University of Chinese Academy of Sciences, Shenzhen, Guangdong, China, 518083

${ }^{*}$ To whom correspondence should be addressed.

Siqi Liu, BGI-Shenzhen, Beishan Industrial Zone 11th building, Yantian District, Shenzhen, Guangdong, China, 518083.

Tel: 86-755-36307403; E-mail: siqiliu@genomics.cn

Yan Ren, BGI-Shenzhen, Beishan Industrial Zone 11th building, Yantian District, Shenzhen, Guangdong, China, 518083.

Tel: 86-755-36307403; E-mail: reny@genomics.cn 
Lists of supplementary components

The article contains Supplementary Figures, Figure S1 to S3, and Supplementary Tables, Table S1 to S7.

Supplementary Table S1: Statistics of karyotypes in different passage stages. ..3 Supplementary Table S2: The list of identified transcripts in the Ker-CT and control cell line. .3

Supplementary Table S3: Identification of MP transcripts on chromosomes 5 and 20 in the Ker-CT and control cell line. .3

Supplementary Table S4: The list of identified proteins and peptides in the Ker-CT and control cell line. .5

Supplementary Table S5: Karyotypes information of 12 cell lines from ATCC.5

Supplementary Table S6: Analysis of MPs identified in 5 cell lines which reported in MP study.

Supplementary Table S7: The Universal Spectrum Identifiers (USIs) for the spectra of native and synthetic peptides validated in the PRM experiment. ..7

Supplementary Figure S1: Distribution of the abundance of the transcripts of all genes.

Supplementary Figure S2 :The spectra of 3 MPs identified in Ker-CT cell line. .10

Supplementary Figure S3: The PRM results of other two MPs. .13 
Supplementary Table S1: Statistics of karyotypes in different passage stages.

\begin{tabular}{|c|c|c|c|c|c|}
\hline \multicolumn{3}{|c|}{ Ker-CT cell line } & \multicolumn{3}{|c|}{ Farage cell line } \\
\hline $\begin{array}{l}\text { Passage } \\
\text { number }\end{array}$ & Karyotype & $\begin{array}{l}\text { Number of } \\
\text { cells }\end{array}$ & $\begin{array}{l}\text { Passage } \\
\text { number }\end{array}$ & Karyotype & $\begin{array}{l}\text { Number of } \\
\text { cells }\end{array}$ \\
\hline \multirow[t]{2}{*}{ No.4 } & $48, \mathrm{XY},+5,+20$ & 4 & No.10 & 46, XX & 14 \\
\hline & $46, \mathrm{XY},-3,+5,+20,-21$ & 1 & & $45, \mathrm{XX},-13$ & 1 \\
\hline \multirow[t]{3}{*}{ No.5 } & $49, \mathrm{XY},+5,+20,+20$ & 6 & & $47, \mathrm{XX},+20$ & 1 \\
\hline & $48, \mathrm{XY},+5,+20$ & 5 & & $47, \mathrm{XX},+11$ & 1 \\
\hline & $47, \mathrm{XY},+5,-17,+20$ & 1 & No.11 & $46, X X$ & 7 \\
\hline \multirow[t]{6}{*}{ No.6 } & $49, \mathrm{XY},+5,+20,+20$ & 2 & & $45, X X,-18$ & 1 \\
\hline & $48, \mathrm{XY},+5,+20$ & 5 & & $44, \mathrm{XX},-6,-14$ & 1 \\
\hline & $46, \mathrm{XY},+5,-9,+20,-19$ & 1 & & $43, \mathrm{XX},-3,-3,-4$ & 1 \\
\hline & & & No.12 & $46, X X$ & 9 \\
\hline & & & & $43, X X,-15,-16,-17$ & 1 \\
\hline & & & & $45, \mathrm{XX},-11$ & 1 \\
\hline
\end{tabular}

Supplementary Table S2: The list of identified transcripts in the Ker-CT and control cell line. (XLSX)

Supplementary Table S3: Identification of MP transcripts on chromosomes 5 and 20 in the Ker-CT and control cell line.

\begin{tabular}{|c|c|c|c|}
\hline MP transcript & Chromosome & $\begin{array}{c}\text { Ker-CT expression } \\
{[\text { FPKM }]}\end{array}$ & $\begin{array}{c}\text { Control expression } \\
\text { [FPKM }]\end{array}$ \\
\hline$P C D H G A 5$ & chr5 & 11.913 & 39.056 \\
\hline$P C D H G A 1$ & chr5 & 11.910 & 38.134 \\
\hline PCDHGA & chr5 & 9.653 & 31.003 \\
\hline PCDHACl & $\operatorname{chr} 5$ & 7.567 & 0.099 \\
\hline$I G I P$ & $\operatorname{chr} 5$ & 3.632 & 2.227 \\
\hline$M T R N R 2 L 2$ & $\operatorname{chr} 5$ & 3.520 & 5.600 \\
\hline РСDHA9 & chr5 & 3.515 & 0.094 \\
\hline ATP6AP1L & $\operatorname{chr} 5$ & 1.265 & 0.214 \\
\hline PLAC8L1 & $\operatorname{chr} 5$ & 0.806 & 0.102 \\
\hline$A N K D D 1 B$ & $\operatorname{chr} 5$ & 0.157 & 0.028 \\
\hline SHISAL2B & $\operatorname{chr} 5$ & 0.142 & 0.033 \\
\hline$S L C 4 A 9$ & $\operatorname{chr} 5$ & 0.079 & \\
\hline ZDHНC11B & $\operatorname{chr} 5$ & 0.063 & 0.015 \\
\hline LINC01554 & $\operatorname{chr} 5$ & 0.024 & 0.054 \\
\hline TMEM232 & $\operatorname{chr} 5$ & 0.005 & 0.002 \\
\hline$S M A D 5-A S 1$ & $\operatorname{chr} 5$ & & 0.081 \\
\hline C5orf67 & $\operatorname{chr} 5$ & & 0.008 \\
\hline SLC6A18 & $\operatorname{chr} 5$ & & \\
\hline C5orf64 & $\operatorname{chr} 5$ & & \\
\hline MINAR2 & $\operatorname{chr} 5$ & & \\
\hline
\end{tabular}




\begin{tabular}{|c|c|c|c|}
\hline SMIM32 & $\operatorname{chr} 5$ & & \\
\hline SMIM33 & $\operatorname{chr} 5$ & & \\
\hline$G R X C R 2$ & $\operatorname{chr} 5$ & & \\
\hline SPINK14 & $\operatorname{chr} 5$ & & \\
\hline$S L C 36 A 3$ & $\operatorname{chr} 5$ & & \\
\hline SMIM23 & $\operatorname{chr} 5$ & & \\
\hline$O R 2 Y 1$ & $\operatorname{chr} 5$ & & \\
\hline OR2V1 & $\operatorname{chr} 5$ & & \\
\hline OR2V2 & $\operatorname{chr} 5$ & & \\
\hline$H E R V-K 104$ & $\operatorname{chr} 5$ & & \\
\hline$E R V K-10$ & $\operatorname{chr} 5$ & & \\
\hline ARHGAP40 & $\operatorname{chr} 20$ & 7.446 & 0.035 \\
\hline NEURL2 & $\operatorname{chr} 20$ & 1.130 & 0.855 \\
\hline$N N A T$ & $\operatorname{chr} 20$ & 1.081 & 0.462 \\
\hline MTRNR2L3 & $\operatorname{chr} 20$ & 0.281 & \\
\hline$E F C A B 8$ & $\operatorname{chr} 20$ & 0.195 & 0.075 \\
\hline GNRH2 & $\operatorname{chr} 20$ & 0.174 & 0.038 \\
\hline C20orf197 & $\operatorname{chr} 20$ & 0.168 & 0.003 \\
\hline GCNT7 & $\operatorname{chr} 20$ & 0.145 & 0.055 \\
\hline FER1L4 & $\operatorname{chr} 20$ & 0.079 & 0.534 \\
\hline TTLL9 & $\operatorname{chr} 20$ & 0.040 & 0.014 \\
\hline GGTLC1 & $\operatorname{chr} 20$ & 0.015 & 0.014 \\
\hline FAM182A & $\operatorname{chr} 20$ & 0.013 & 0.028 \\
\hline SCRT2 & $\operatorname{chr} 20$ & 0.013 & \\
\hline FAM182B & $\operatorname{chr} 20$ & 0.009 & 0.024 \\
\hline C20orf203 & $\operatorname{chr} 20$ & 0.008 & 0.002 \\
\hline IIR1-1HG-AS1 & $\operatorname{chr} 20$ & & 0.035 \\
\hline$T M C 2$ & $\operatorname{chr} 20$ & & 0.005 \\
\hline$D E F B 125$ & $\operatorname{chr} 20$ & & \\
\hline TCF 15 & $\operatorname{chr} 20$ & & \\
\hline$S C P 2 D 1$ & $\operatorname{chr} 20$ & & \\
\hline SSTR4 & $\operatorname{chr} 20$ & & \\
\hline CSTL1 & $\operatorname{chr} 20$ & & \\
\hline CST9 & $\operatorname{chr} 20$ & & \\
\hline DEFB 116 & $\operatorname{chr} 20$ & & \\
\hline$D E F B 123$ & $\operatorname{chr} 20$ & & \\
\hline$A D I G$ & $\operatorname{chr} 20$ & & \\
\hline$R 3 H D M L$ & $\operatorname{chr} 20$ & & \\
\hline WFDC10A & $\operatorname{chr} 20$ & & \\
\hline WFDC11 & $\operatorname{chr} 20$ & & \\
\hline OCSTAMP & $\operatorname{chr} 20$ & & \\
\hline- & $\operatorname{chr} 20$ & & \\
\hline$M I R 1-1 H G$ & $\operatorname{chr} 20$ & & \\
\hline
\end{tabular}


Supplementary Figure S1: Distribution of the abundance of the transcripts of all genes.

A) Comparison of the average abundance of overlapped transcripts in individual chromosomes between Ker-CT and control cell line. B) Comparison of the average abundance of specific transcripts of non-MP genes in individual chromosomes only detected in Ker-CT or control cell line. 


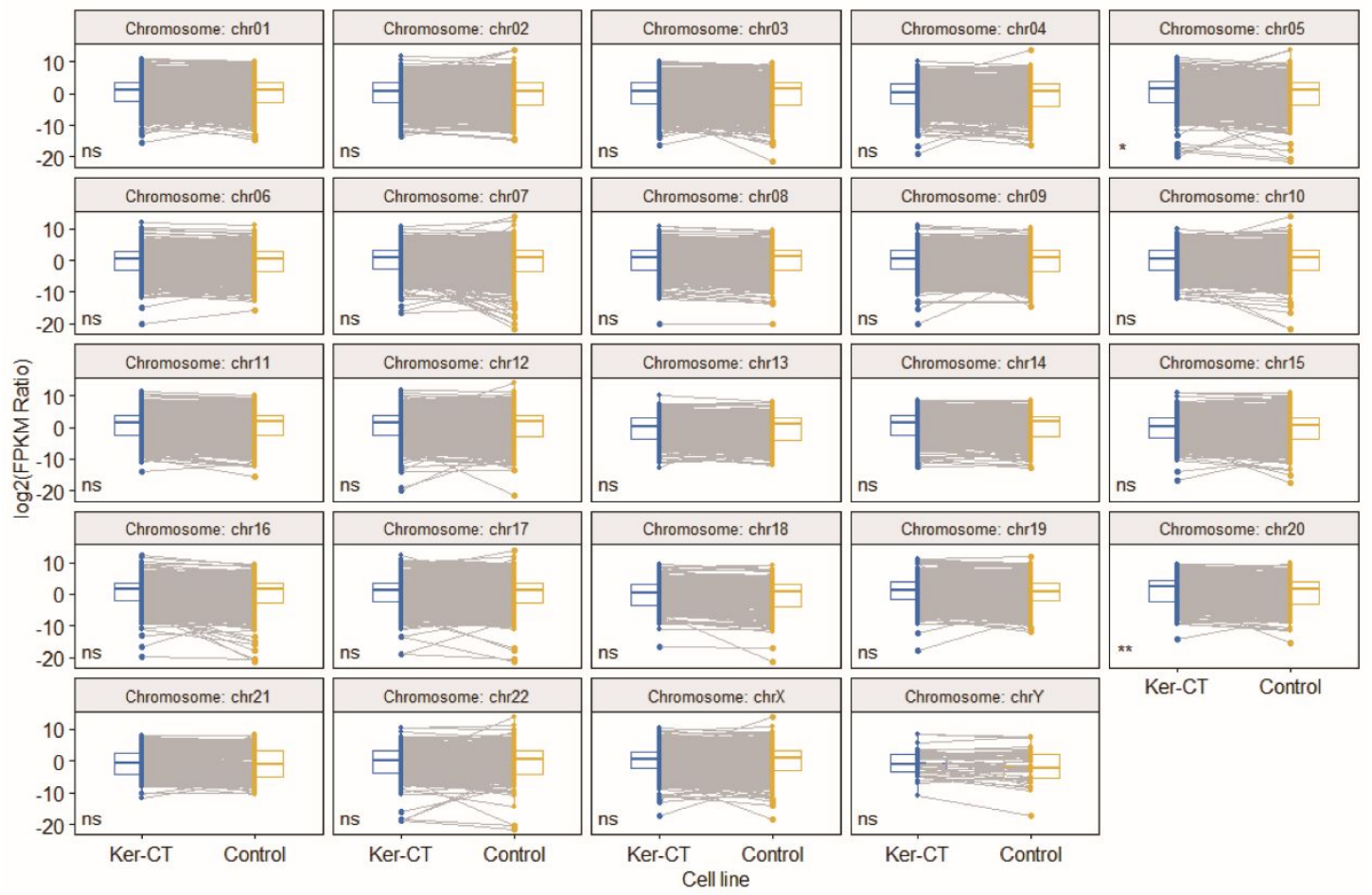

B Comparison of specific transcripts of non-MP genes

Group - only in Control * only in Ker-CT

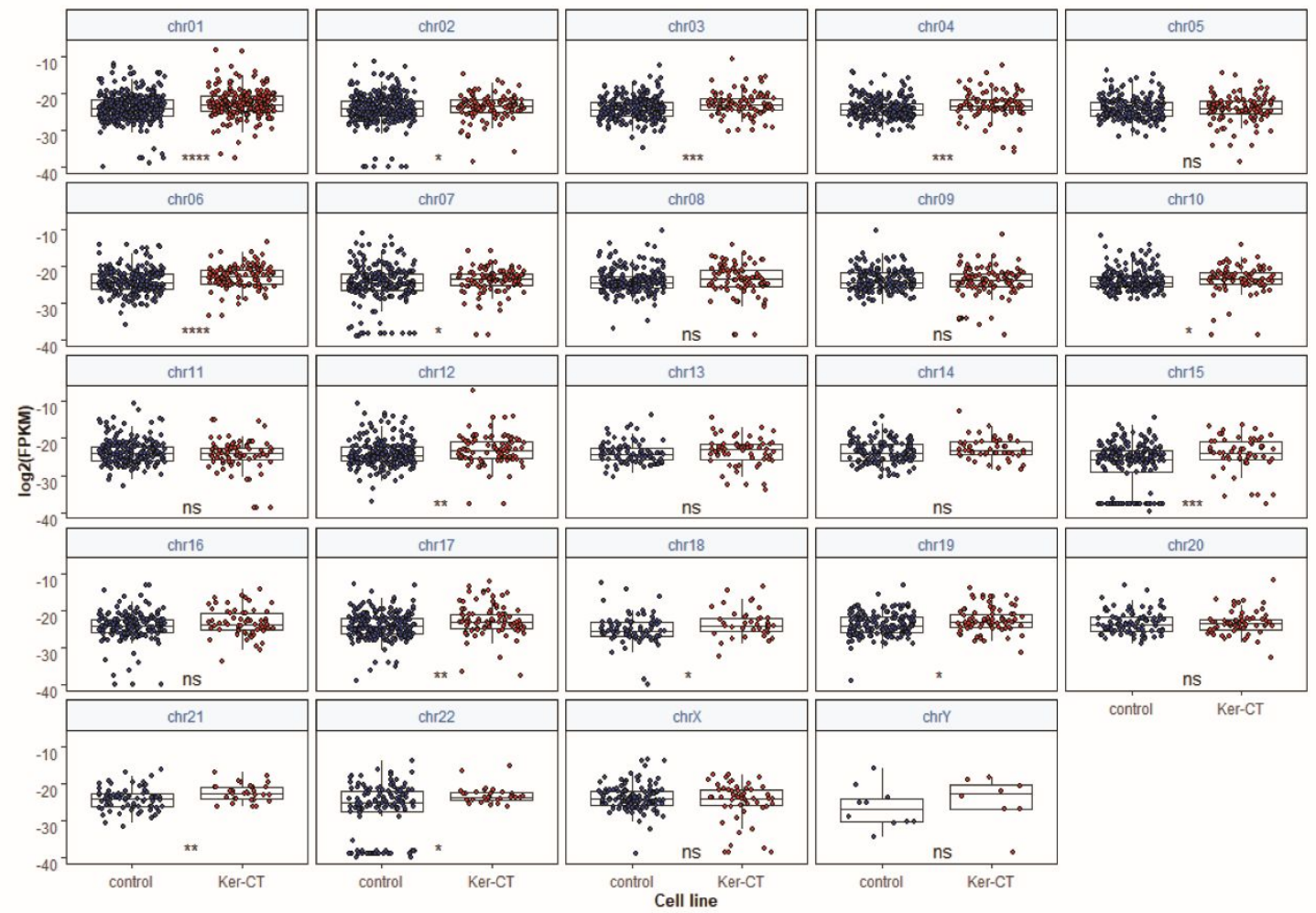

Supplementary Table S4: The list of identified proteins and peptides in the Ker-CT and control cell line. (XLSX) 
Supplementary Table S5: Karyotypes information of 12 cell lines from ATCC.

\begin{tabular}{|c|c|}
\hline Cell line & Karyotype \\
\hline MCF7 & $\begin{array}{l}\text { modal number }=82 \text {; range }=66 \text { to } 87 . \\
\text { The stemline chromosome numbers ranged from hypertriploidy to hypotetraploidy, with the } 2 \mathrm{~S} \\
\text { component occurring at } 1 \% \text {. There were } 29 \text { to } 34 \text { marker chromosomes per S metaphase; } 24 \text { to } \\
28 \text { markers occurred in at least } 30 \% \text { of cells, and generally one large submetacentric (M1) and } 3 \\
\text { large subtelocentric (M2, M3, and M4) markers were recognizable in over } 80 \% \text { of metaphases. } \\
\text { No DM were detected. Chromosome } 20 \text { was nullisomic and X was disomic. }\end{array}$ \\
\hline LoVo & $\begin{array}{l}\text { The stemline chromosome number is hyperdiploid with the } 2 \mathrm{~S} \text { component occurring at about } \\
2.7 \% \text { and } 3 \text { marker chromosomes were common to all } \mathrm{S} \text { metaphases. Karyotypes were generally } \\
\text { homogeneous and stable. }\end{array}$ \\
\hline SNU-1 & $\begin{array}{l}\text { SNU-1 is a near-diploid cell line with a modal chromosome number of } 47 \text {; double minute } \\
\text { chromosomes were found in } 28 \% \text { of the cells. They have a reported colony-forming efficiency } \\
\text { of } 1.9 \% \text { in semisolid medium and a population doubling time of } 26 \text { hours. The cells grow as } \\
\text { floating aggregates of round cell clusters. This is a hyperdiploid human cell line with the modal } \\
\text { chromosome number of } 47 \text { occurring in } 94 \% \text { of cells. Higher ploidies occurred at } 42 \% \text {, which is } \\
\text { very high. The karyotype of } 47, \mathrm{XY}, \mathrm{t}(1 ; 4)(\mathrm{q} 24 ; \mathrm{q} 33),+\mathrm{M} 1 \text { is very uniform and stable. M1 is an } \\
\text { F- sized small metacentric chromosome. }\end{array}$ \\
\hline $\mathrm{CaCo}-2$ & $\begin{array}{l}\text { The stemline modal chromosome number is } 96 \text {, occurring at } 16 \% \text { with polyploidy at } 3.2 \% \text {. Ten } \\
\text { common markers were detected i.e., } \mathrm{t}(1 \mathrm{q} ; ?), 10 \mathrm{q}-\mathrm{t}(11 \mathrm{q} 17 \mathrm{q}) \text { and } 7 \text { others. The } \mathrm{t}(1 \mathrm{q} 17 \mathrm{q}) \text { and } \\
\text { M11 were found in a portion of cells. The ins }(2), 10 \mathrm{q}-\text {, and } \mathrm{t}(15 \mathrm{q} ; ?) \text { were generally paired, and } \\
\mathrm{t}(11 \mathrm{q} ; 17 \mathrm{q}) \text { and } \mathrm{t}(21 \mathrm{q} ; ?) \text { were mostly three-copied. Normal N9 was absent, and N21 was lost in } \\
\text { some cells. One to } 4 \text { small acrocentric chromosomes were detected. No Y chromosome with } \\
\text { bright distal q-band was detected by Q-observation. }\end{array}$ \\
\hline SW480 & $\begin{array}{l}\text { The stemline chromosome number is hypotriploid and } 11-12 \text { marker chromosomes were } \\
\text { common. Both double minutes and dicentrics were observed in } 8 \% \text { of each metaphase } \\
\text { examined. }\end{array}$ \\
\hline HeLa & $\begin{array}{l}\text { Modal number }=82 \text {; range }=70 \text { to } 164 \text {. } \\
\text { There is a small telocentric chromosome in } 98 \% \text { of the cells. } 100 \% \text { aneuploidy in } 1385 \text { cells } \\
\text { examined. Four typical HeLa marker chromosomes have been reported in the literature. HeLa } \\
\text { Marker Chromosomes: One copy of M1, one copy of M2, four-five copies of M3, and two } \\
\text { copies of M4 as revealed by G-banding patterns. M1 is a rearranged long arm and centromere of } \\
\text { chromosome } 1 \text { and the long arm of chromosome } 3 . \mathrm{M} 2 \text { is a combination of short arm of } \\
\text { chromosome } 3 \text { and long arm of chromosome } 5 . \mathrm{M} 3 \text { is an isochromosome of the short arm of } \\
\text { chromosome } 5 . \mathrm{M} 4 \text { consists of the long arm of chromosome } 11 \text { and an arm of chromosome } 19 \text {. }\end{array}$ \\
\hline NCI_N87 & near diploid \\
\hline Hep G2 & modal number $=55($ range $=50$ to 60$) ;$ has a rearranged chromosome 1 \\
\hline A549 & $\begin{array}{l}\text { This is a hypotriploid human cell line with the modal chromosome number of } 66 \text {, occurring in } \\
24 \% \text { of cells. Cells with } 64(22 \%), 65 \text {, and } 67 \text { chromosome counts also occurred at relatively } \\
\text { high frequencies; the rate with higher ploidies was low at } 0.4 \% \text {. There were } 6 \text { markers present in } \\
\text { single copies in all cells. They include der(6)t(1;6) (q11;q27); ?del(6) (p23); del(11) (q21), } \\
\text { del(2) (q11), M4 and M5. Most cells had two X and two Y chromosomes. However, one or both }\end{array}$ \\
\hline
\end{tabular}


Y chromosomes were lost in $40 \%$ of 50 cells analyzed. Chromosomes N2 and N6 had single copies per cell; and N12 and N17 usually had 4 copies.

HEK 293 This is a hypotriploid human cell line. The modal chromosome number was 64, occurring in $30 \%$ of cells. The rate of cells with higher ploidies was $4.2 \%$. The $\operatorname{der}(1) \mathrm{t}(1 ; 15)$ (q42;q13), $\operatorname{der}(19) \mathrm{t}(3 ; 19)$ (q12; 13$), \operatorname{der}(12) \mathrm{t}(8 ; 12)$ (q22;p13), and four other marker chromosomes were common to most cells. Five other markers occurred in some cells only. The marker der(1) and M8 (or $\mathrm{Xq}^{+}$) were often paired. There were four copies of N17 and N22. Noticeably in addition to three copies of $\mathrm{X}$ chromosomes, there were paired $\mathrm{Xq}+$, and a single $\mathrm{Xp}+$ in most cells.

K-562 The stemline chromosome number is triploid with the $2 \mathrm{~S}$ component occurring at $4.2 \%$. Fifteen markers (M1 to M15) occurred in nearly all S metaphases. Spontaneous non-specific dicentrics occurred, but rarely. Unstable markers were also rarely seen. The X was disomic, and N9 was nullisomic.

Supplementary Table S6: Analysis of MPs identified in 5 cell lines which reported in MP study.

\begin{tabular}{ccccc}
\hline Protein & Gene & Cell line & Chromosome & TPM \\
\hline Q8IZF3 & ADGRF4 & A549 & chr6 & 1.1 \\
Q8N9W4 & GOLGA6L2 & A549 & chr15 & 0 \\
Q96HM7 & PCED1B & A549 & chr12 & 57.3 \\
Q2TB18 & ASTE1 & A549 & chr3 & 6.2 \\
Q8N3J9 & ZNF664 & A549 & chr12 & 54.8 \\
Q64LD2 & WDR25 & A549 & chr14 & 5.5 \\
Q9Y6Q3 & ZFP37 & A549 & chr9 & 1.5 \\
Q9HCL3 & ZFP14 & A549 & chr19 & 2.3 \\
Q9HB15 & C3orf14 & A549 & chr3 & 26.1 \\
O60422 & ONECUT3 & SNU-1 & chr19 & 0.3 \\
A6NJ46 & NKX6-3 & SNU-1 & chr8 & 5.6 \\
Q8N8Y5 & ZFP41 & Hep G2 & chr8 & 2.8 \\
Q6B0B8 & TIGD3 & Hep G2 & chr11 & 1.9 \\
Q9P217 & ZSWIM5 & Hep G2 & chr1 & 4.1 \\
O00624 & SLC17A2 & Hep G2 & chr6 & 2.5 \\
Q16534 & HLF & Hep G2 & chr17 & 110.5 \\
Q86X67 & NUDT13 & Hep G2 & chr10 & 3.3 \\
A6NKX4 & SLC22A31 & Hep G2 & chr16 & 19.4 \\
Q7Z4H4 & ADM2 & Hep G2 & chr22 & 1.9 \\
Q9NR64 & KLHL1 & HeLa & chr13 & 1.6 \\
Q8N319 & C6orf223 & HeLa & chr6 & 3.1 \\
Q9HCC6 & HES4 & HeLa & chr1 & 1.4 \\
O15375 & SLC16A5 & HeLa & chr17 & 20.4 \\
Q8N413 & SLC25A45 & HeLa & chr11 & 2.1 \\
Q6ZNX1 & AC008560.1 & HeLa & chr5 & 5.8 \\
Q9H7M6 & ZSWIM4 & HeLa & chr19 & 3.6 \\
B1AL88 & FAM155A & HeLa & chr13 & 0 \\
& & & &
\end{tabular}




\begin{tabular}{ccccc} 
Q7Z2Y8 & & HeLa & chr11 & \\
Q9Y493 & ZAN & HeLa & chr7 & 0 \\
Q5XG99 & LYSMD4 & HeLa & chr15 & 4.4 \\
Q6UXU6 & TMEM92 & HeLa & chr17 & 1.3 \\
Q7Z5J1 & HSD11B1L & HeLa & chr19 & 1.9 \\
Q9NXS3 & KLHL28 & HeLa & chr14 & 4.5 \\
A4D0V7 & CPED1 & K562 & chr7 & 157.8 \\
Q5T292 & C10orf128 & K562 & chr10 & 90.9 \\
Q8N6I4 & TMEM251 & K562 & chr14 & 9 \\
P48201 & ATP5MC3 & K562 & chr2 & 514.8 \\
Q3C1V8 & $B S X$ & K562 & chr11 & 0 \\
Q6ZTK2 & & K562 & chr16 & \\
Q8N614 & TMEM156 & K562 & chr4 & 5.1 \\
\hline
\end{tabular}


Supplementary Table S7: The Universal Spectrum Identifiers (USIs) for the spectra of native and synthetic peptides validated in the PRM experiment.

\begin{tabular}{|c|c|c|c|}
\hline Protein & $\begin{array}{l}\text { Non-nested unique } \\
\text { peptide }\end{array}$ & USIs of natural peptide & USIs of synthetic peptide \\
\hline Q17RR3 & EYIHAVNNLR & $\begin{array}{c}\text { mzspec:PXD028647:PRM_480_native_peptide:scan:6675:EY } \\
\text { IHAVNNLR/2 }\end{array}$ & $\begin{array}{c}\text { mzspec:PXD028647:PRM_480_synthetic_peptide:scan:14253:EYI } \\
\text { HAVNNLR/2 }\end{array}$ \\
\hline Q17RR3 & LGAEMVINTSGK & $\begin{array}{c}\text { mzspec:PXD028647:PRM_480_native_peptide:scan:8634:LG } \\
\text { AEMVINTSGK/2 }\end{array}$ & $\begin{array}{c}\text { mzspec:PXD028647:PRM_480_synthetic_peptide:scan:17948:LGA } \\
\text { EMVINTSGK/2 }\end{array}$ \\
\hline C9JBD0 & ESCFTQPQGVLSR & $\begin{array}{l}\text { mzspec:PXD028647:PRM_480_native_peptide:scan:8724:ES } \\
\text { C[UNIMOD:4]FTQPQGVLSR/2 }\end{array}$ & $\begin{array}{c}\text { mzspec:PXD028647:PRM_480_synthetic_peptide:scan:18183:ESC }[ \\
\text { UNIMOD:4]FTQPQGVLSR/2 }\end{array}$ \\
\hline C9JBD0 & AGWIGYLELR & $\begin{array}{c}\text { mzspec:PXD028647:PRM_480_native_peptide:scan:13521:A } \\
\text { GWIGYLELR/2 }\end{array}$ & $\begin{array}{c}\text { mzspec:PXD028647:PRM_480_synthetic_peptide:scan:27915:AG } \\
\text { WIGYLELR/2 }\end{array}$ \\
\hline Q9BY21 & VVKPFGDSR & $\begin{array}{c}\text { mzspec:PXD028647:PRM_480_native_peptide:scan:4789:VV } \\
\text { KPFGDSR/2 }\end{array}$ & $\begin{array}{c}\text { mzspec:PXD028647:PRM_480_synthetic_peptide:scan:10410:VVK } \\
\text { PFGDSR/2 }\end{array}$ \\
\hline Q9BY21 & IPFTFSHLDR & $\begin{array}{c}\text { mzspec:PXD028647:PRM_480_native_peptide:scan:9179:IPF } \\
\text { TFSHLDR/2 }\end{array}$ & $\begin{array}{c}\text { mzspec:PXD028647:PRM_480_synthetic_peptide:scan:19222:IPFT } \\
\text { FSHLDR/2 }\end{array}$ \\
\hline
\end{tabular}


Supplementary Figure $\mathbf{S 2}$ :The spectra of 3 MPs identified in Ker-CT cell line.

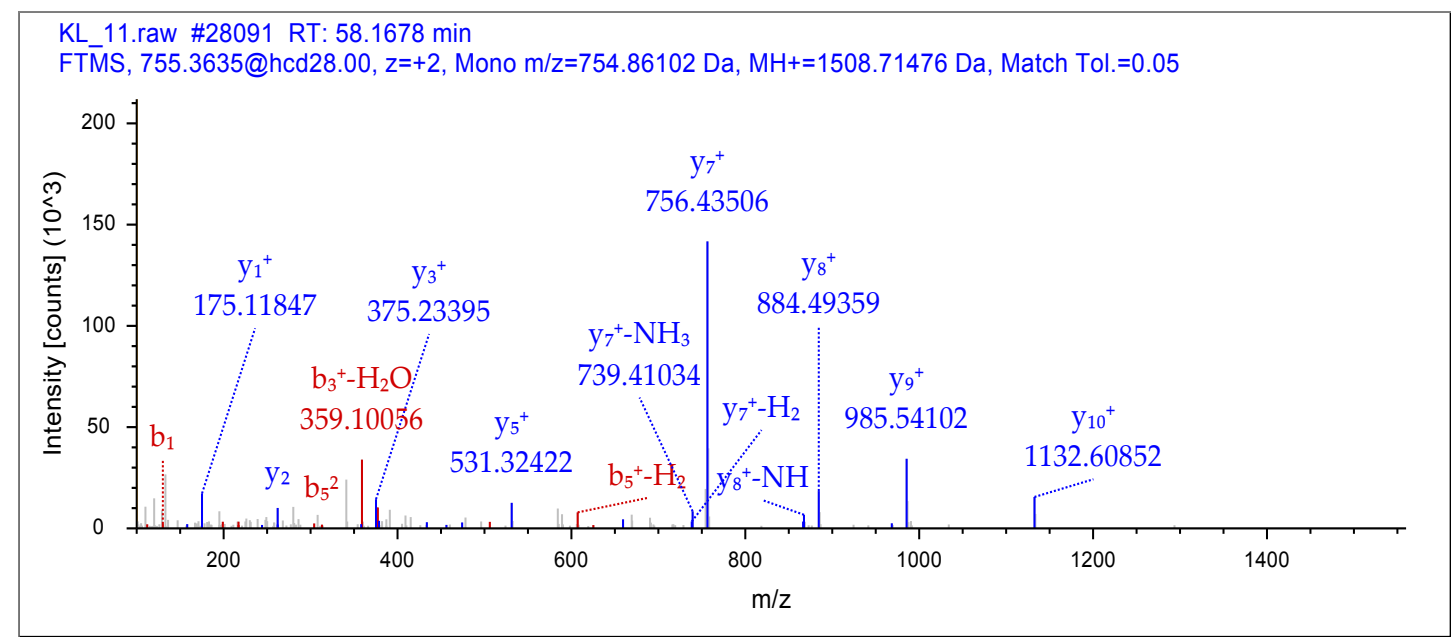

ESCFTQPQGVLSR of C9JBD0 protein

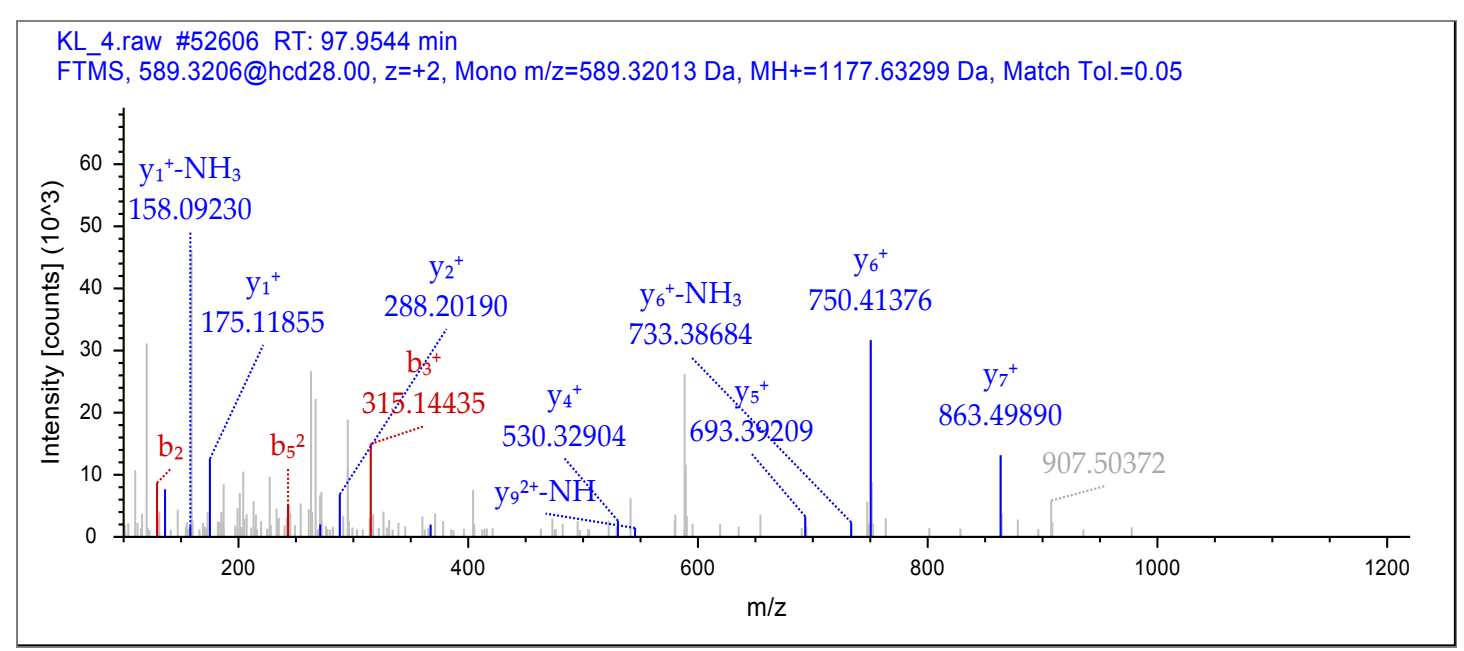

AGWIGYLELR of C9JBD0 protein

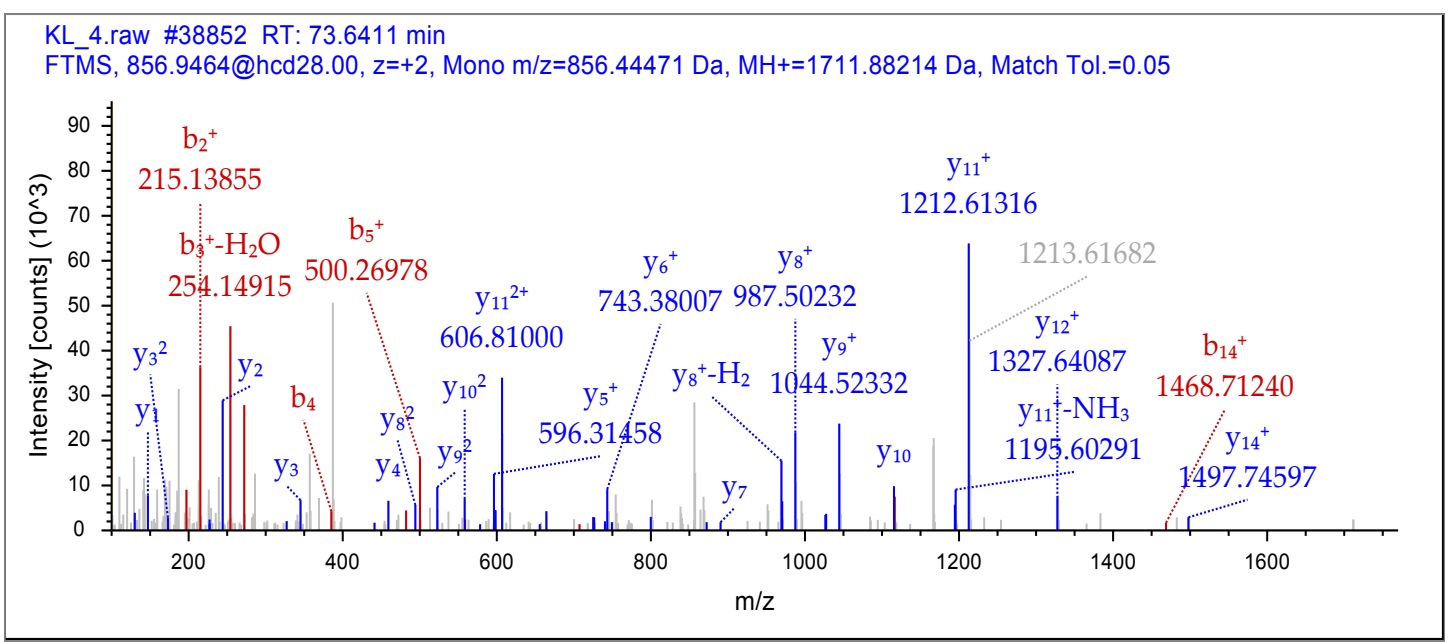

ITGLDPAGPFFHNTPK of Q17RR3 protein 


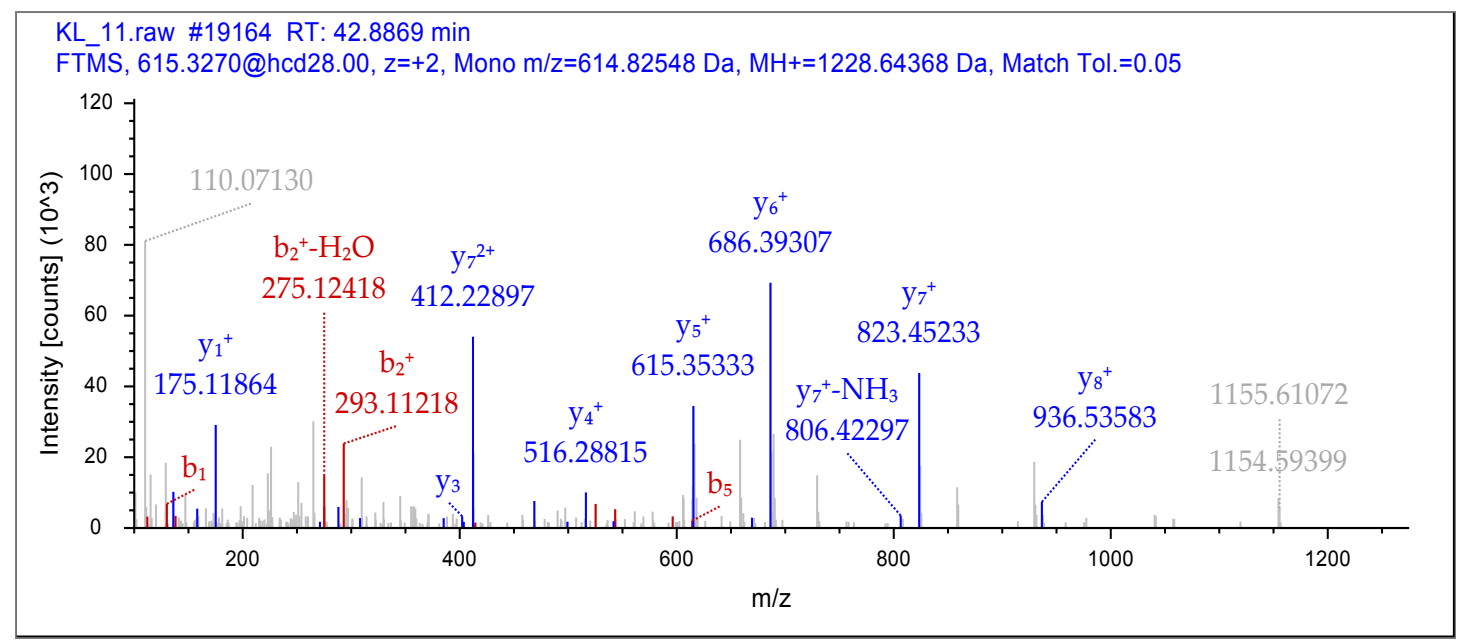

EYIHAVNNLR of Q17RR3 protein

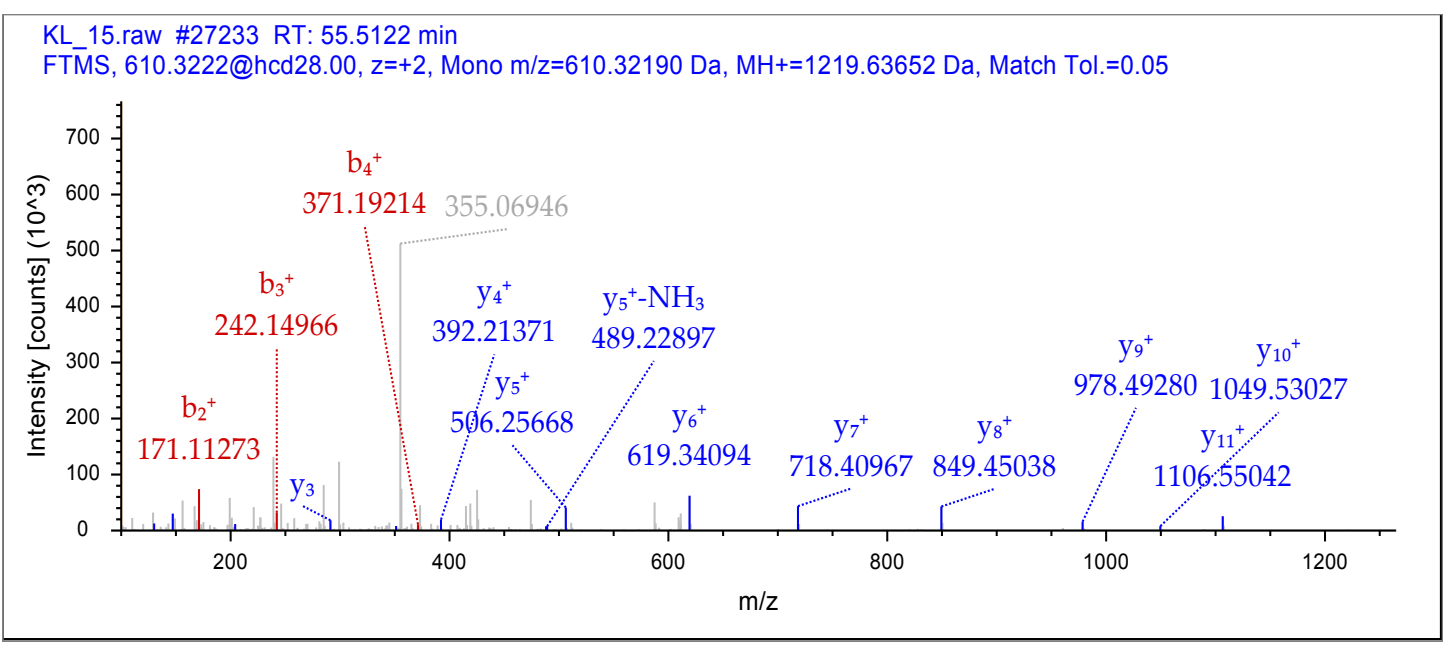

LGAEMVINTSGK of Q17RR3 protein

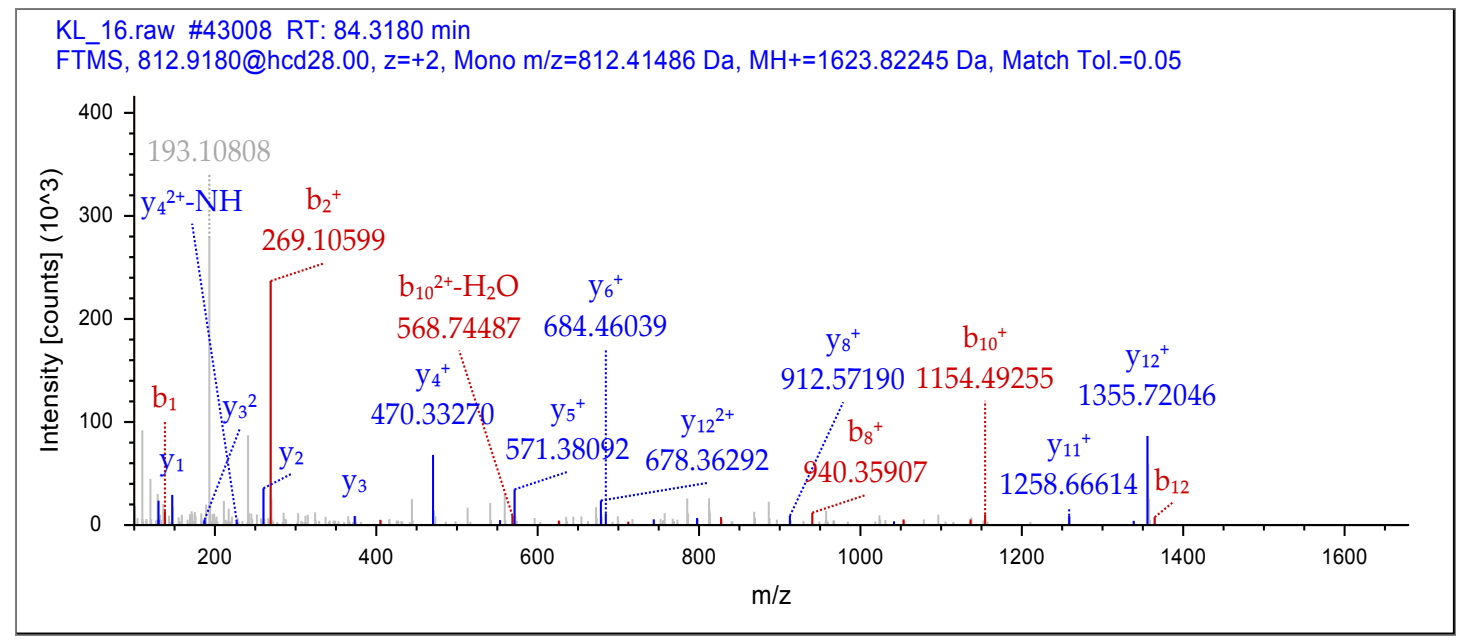

HMPGCEDLITPLLK of Q17RR3 protein 


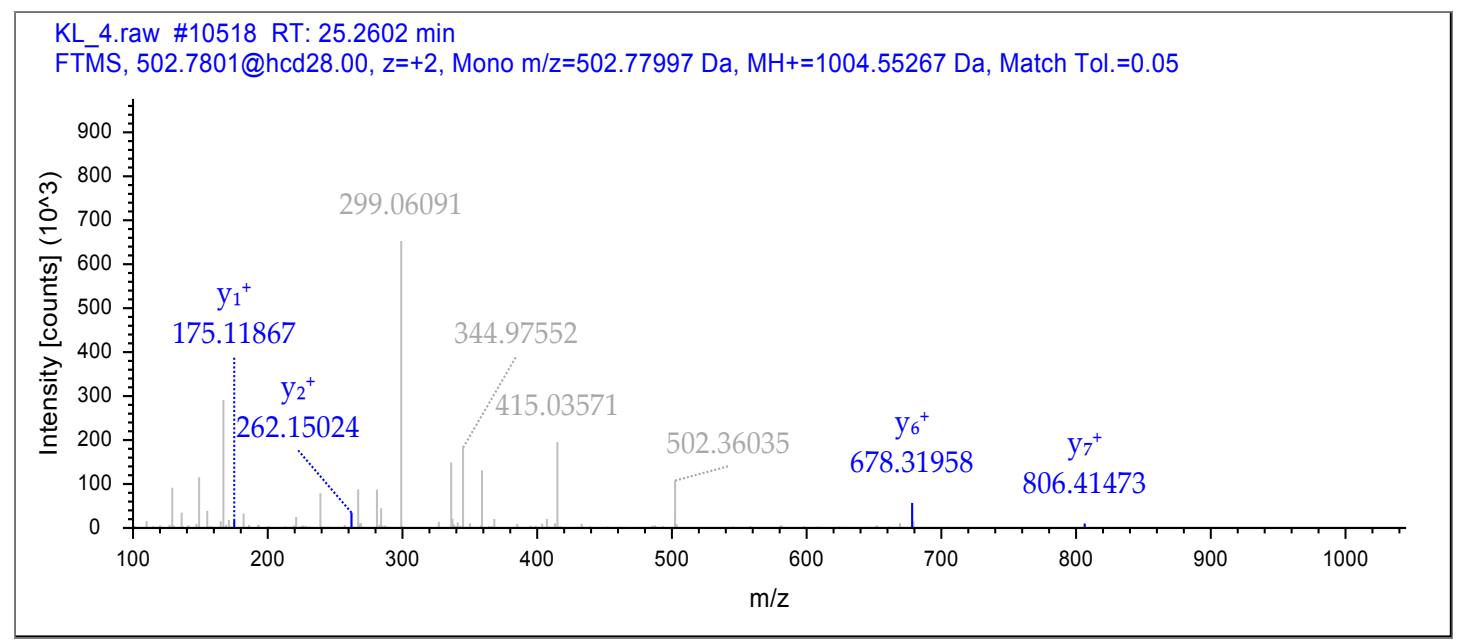

VVKPFGDSR of Q9BY21 protein

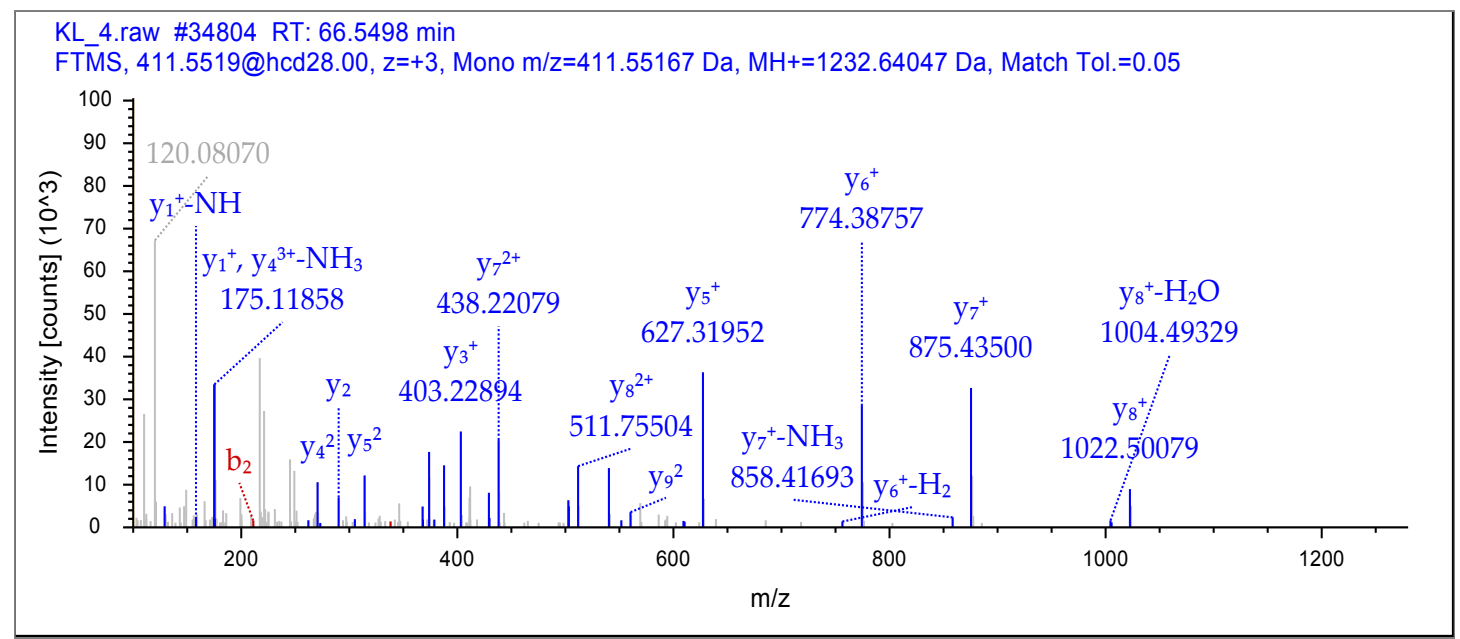

IPFTFSHLDR of Q9BY21 protein 
Supplementary Figure S3: The PRM results of other two MPs.
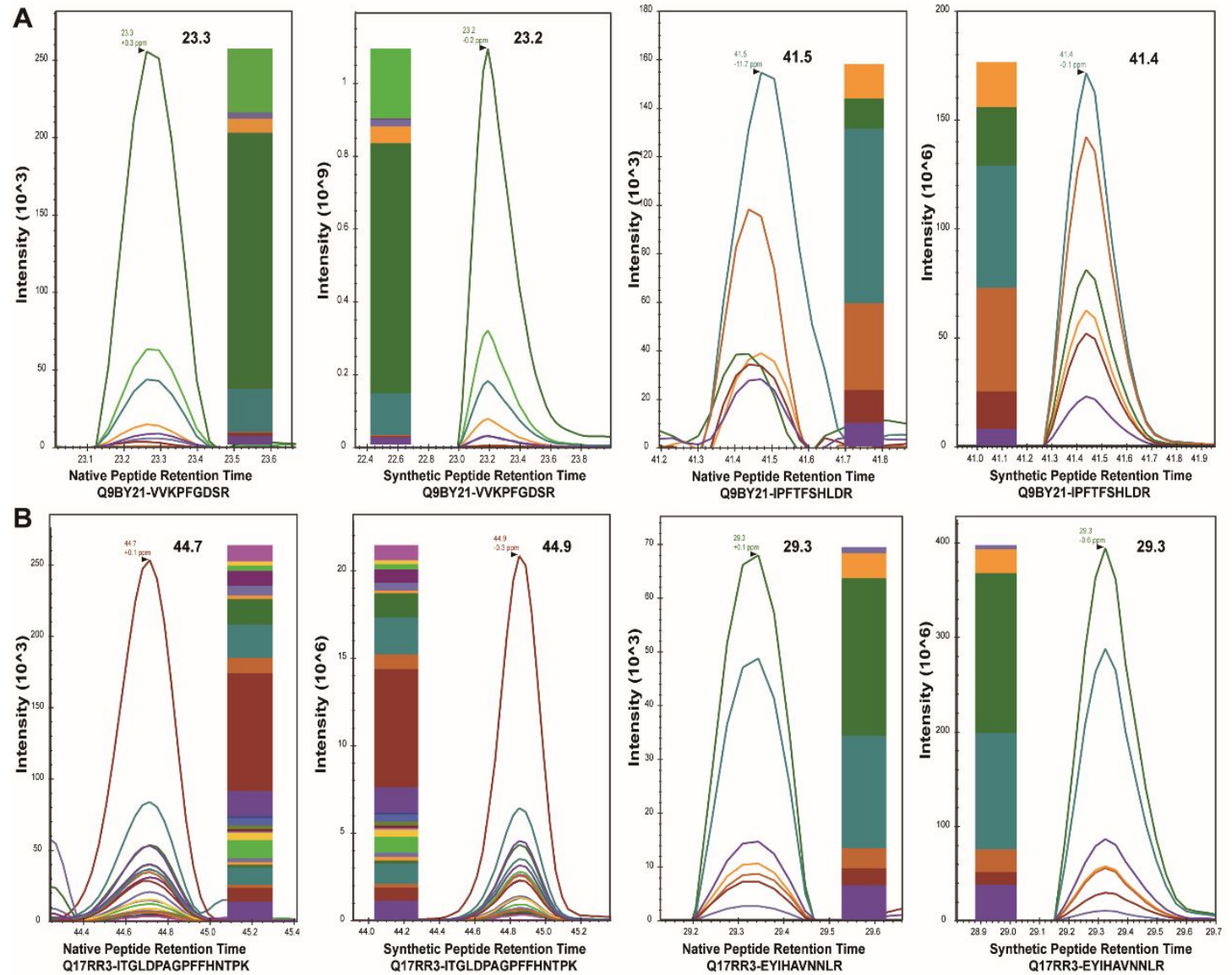